\title{
Morphological and Physicochemical Properties of Termite Mounds in the Mixed Deciduous Forests of Thailand
}

\author{
Paiphan Paejaroen ${ }^{1}$ \\ Chetsada Phaenark ${ }^{1}$ \\ Supatra Chunchob ${ }^{1}$ (a) \\ Weerachon Sawangproh ${ }^{1}$ \\ ${ }^{1}$ Mahidol University, Division of Conservation Biology, School of Interdisciplinary Studies, Sai Yok, Thailand.
}

\begin{abstract}
In this study, we surveyed termites in Thailand and characterized the mounds they built in mixed deciduous forests. We analyzed soil samples from termite mounds for moisture, electrical conductivity, temperature, $\mathrm{pH}$, and soil texture. Three species of wood-feeding termites were identified, including Globitermes sulphureus (47\%), Microcerotermes crassus (32\%), and M. distans (21\%). The sizes of mounds were the largest for G. sulphureus, followed by M. crassus and M. distans. The characteristics of termite mounds were slightly acidic sandy-clay soils for G. sulphureus, slightly acidic sandy-clay-loam soils for M. crassus, and slightly basic sandy-clay soils for M. distans. The PCA revealed three groups of mound individuals without a clear separation of termite species. In future study, it is suggested to use more samples and other soil parameters such as clay minerals of different particle sizes.
\end{abstract}

Keywords: Epigeal mound, granulometry, Isoptera, Termitinae.

\section{INTRODUCTION AND OBJECTIVES}

Termites (Isoptera) are social insects that live in colonies. Many termites are wood feeders, though they may also feed on various kinds of organic matter (Kirton, 2005). Some termites are detritus feeders, meaning they break down dead organic materials in forest ecosystems (Eggleton et al., 1997; Jouquet et al., 2011) and contribute to nutrient cycling and energy flux, thus structuring communities (Holt \& Lepage, 2000; Rückamp et al., 2012). The tunneling efforts of termites also help ensure that soil is porous, aerated and enriched with the minerals and nutrients needed to support better plant growth (Majid \& Ahmad, 2009; Kaiser et al., 2017; Apori et al., 2020). In the tropics, termites are soil invertebrates that play a vital role in soil formation by manipulating mineral constituents (Collins, 1981). For example, mound-building termites help move subsoil from various depths to their above-ground nest structures (Adekayode \& Ogunkoya, 2009; Mujinya et al., 2014). The mounds are nests built from soil taken from different soil depths, sometimes as deep as three meters below ground (Adekayode \& Ogunkoya, 2009). Their roles in changing ecosystems through the modification, maintenance, or creation of habitats for other organisms make them ecosystem engineers (Jouquet et al., 2006; Millogo et al., 2011; Whitford \& Eldridge,
2013). The composition of mound soil is closely related to the physical and chemical properties of the adjacent subsoil (Adekayode \& Ogunkoya, 2009; Bera et al., 2020). The life span of mounds and soil turnover rate depends on various factors such as termite species, soil material, and climatic conditions, as well as biological and physical conditions (Lobry de Bruyn \& Conacher, 1990; Silva et al., 2010).

Thailand is located in the humid tropics, which comprises different forest ecosystems and climatic conditions, providing suitable habitats for termite growth and development (Sornnuwat et al., 2004). Termite nests are easily found in forests, farmland, and rural shelters as well as in human settlements (Sornnuwat et al., 2004). From the most recent update on a systematic key to termites of Thailand by Sornnuwat et al. (2004), 199 species of termites were recorded from 39 genera, 10 subfamilies, and four families. In Thailand, knowledge about termite fauna is scarce - not only from a taxonomic perspective, but other aspects as well including biological diversity, abundance, biomass, behavior, and ecological function (Sornnuwat et al., 2004).

Here, we aim to study the termite species that build epigeal mounds in the vicinity of Mahidol University, which is located in Kanchanaburi Province, Thailand. In a preliminary survey, we observed several termite mounds on the campus. The objectives of the present study are to identify termite species 
and characterize the physicochemical and morphological properties of their termite mounds.

\section{MATERIALS AND METHODS}

\subsection{Study site}

Fieldwork was carried out in the vicinity of Mahidol University (Kanchanaburi Campus) (Figure 1). The physical geography of the campus primarily comprises limestone mountains with a mixed deciduous forest (Kritasampan et al., 2016). The seasonal cycles have three periods: the dry season (mid-February to mid-May), the rainy season (midMay to mid-October), and the cold season (mid-October to mid-February) (Phenrat et al., 2016). Mean annual precipitation is $1097 \mathrm{~mm}$ and mean annual temperature is $26.7^{\circ} \mathrm{C}$ (Sharma \& Babel, 2014). The local climate is tropical savannah (Tienwong et al., 2009).

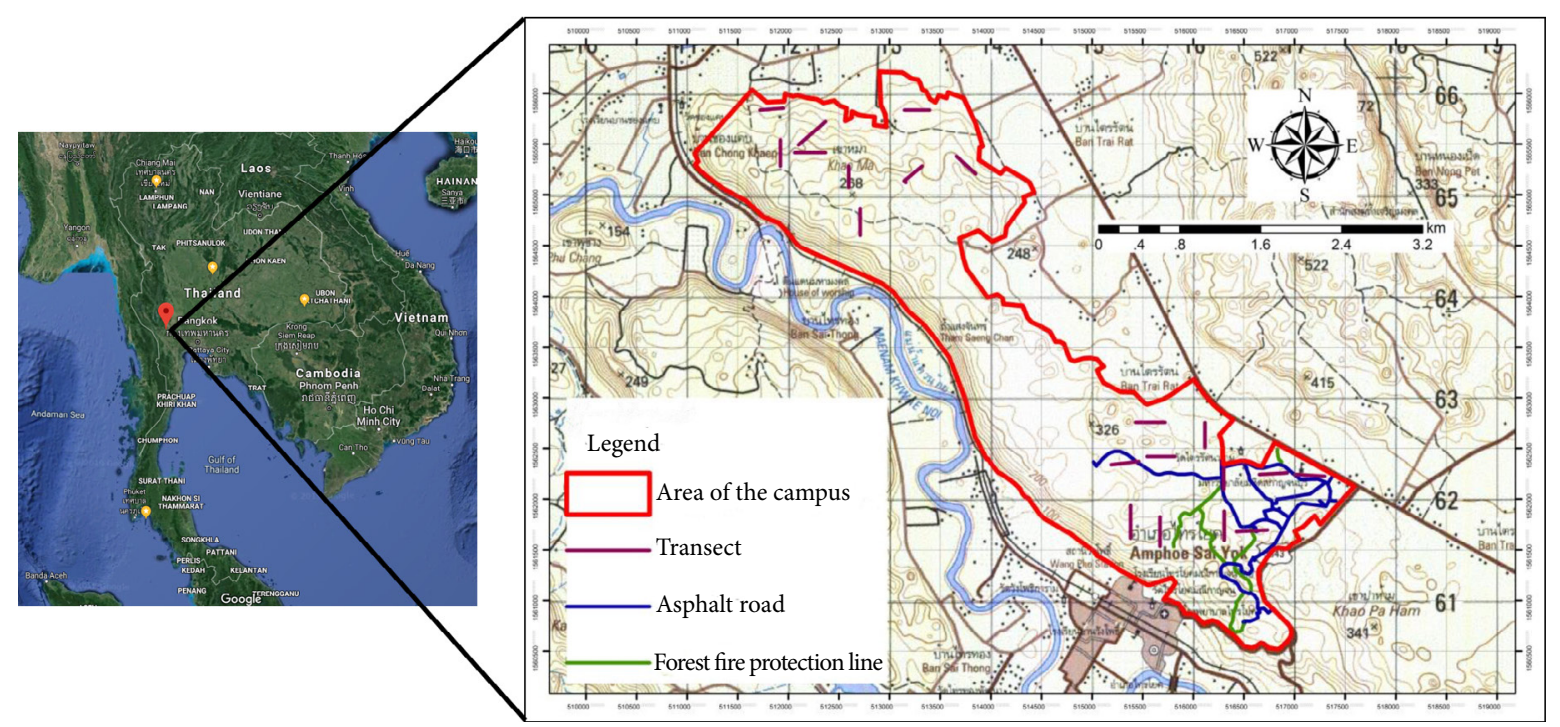

Figure 1. Location of the study site showing 20 belt transects of the termite mound survey.

\subsection{Sampling protocols and species identification}

In this study, we focused on termites that built epigeal mounds (nests growing above the soil surface). Surveys were conducted in November 2014 and March 2015 using belt transects, as described by Palin et al. (2011). Each belt transect was $100 \mathrm{~m}$ long and $2 \mathrm{~m}$ wide. Twenty belt transects were randomly selected beforehand using grid numbers assigned on a paper map (a grid of $100 \times 100 \mathrm{~m}$ ). For each belt transect, a search for termite mounds was done by one person walking continuously on one of four sides of a grid border for an hour. All epigeal mounds encountered were tallied. The vitality of the termite mound was checked by the presence of termites using an iron garden trowel. Soldier termites were collected for species identification under a stereomicroscope using the systematic key to termites of Thailand (Sornnuwat et al., 2004). This study was approved by the Mahidol University-Institute Animal Care and Use Committee, Protocol No. F01-64-004.

\subsection{Mound morphology and physicochemical properties of mound soils}

Following Thongkhong (2009), the three dimensions of epigeal termite mounds were measured in the field: i) basal circumference $(\mathrm{BC})$ - the circumference of the mound at the ground level ii) subapical circumference (SC) - the circumference of the mound at 5 inches below the tip of the mound, and iii) mound height ( $\mathrm{MH})$ - the height of epigeal mound from the ground level. To evaluate the physical and chemical soil properties of termite mounds, the soil inside a termite mound was dug up at a depth of $15 \mathrm{~cm}$ with an iron garden trowel, and then measured for soil temperature $\left({ }^{\circ} \mathrm{C}\right)$ and moisture (\%) with a wet sensor kit (Delta-T Devices). Subsequently, soil samples were collected from various spots inside each mound and put in a zipped bag for granulometry (sand-silt-clay ratio), the measurement of soil $\mathrm{pH}$, and electrical conductivity $(\mathrm{EC} \mu \mathrm{s} / \mathrm{cm}$ ) in a laboratory. Granulometry is a sieve analysis used to determine the particle size distribution 
of sand, silt and clay (ASTM C136 / C136M-14, 2014) based on a soil texture triangle by the United States Department of Agriculture (USDA) (https://www.nrcs.usda.gov/wps/portal/ nrcs/detail/soils/survey/?cid=nrcs142p2_054167). A soil sample of 20 grams taken from the granulometric analysis was subsequently mixed with $20 \mathrm{ml}$ of distilled water and left for about half an hour with occasional stirring. Then, the electrode of a Consort C5010 portable meter was dipped into the solution to read the values for electrical conductivity and soil $\mathrm{pH}$.

\subsection{Data analyses}

The normality and homogeneity of variance were checked using the Shapiro-Wilk test and Levene's test, respectively. Once the assumptions of parametric tests were verified, the data were analyzed using one-way ANOVA, while the mean values were compared with Turkey's HSD tests $(\alpha=0.05)$. The principal components analysis (PCA) was applied for reducing the number of variables into groups of independent components. The principal components (PCs) having eigenvalues greater than 1.0 were kept. The relationships between principal components and soil attributes (e.g., soil moisture, EC, soil temperature, soil $\mathrm{pH}, \%$ clay, \% sand, and $\%$ silt) were tested using Pearson's correlation tests. The association between the soil types and termite species was determined by using the Chi-square test. All statistical analyses were run in $\mathrm{R}$ version 1.1.463 (R Development Core Team, 2018). The PCA analysis was run by using the $R$ packages "FactoMineR" and "Factoextra", and the mean plots were generated by using the R packages "ggpubr".

\section{RESULTS AND DISCUSSION}

\subsection{Occupancy, abundance, species identification, and morphology of mounds}

Sixteen out of 20 transects were occupied by 34 epigeal mounds belonging to three morphospecies of the subfamily Termitinae, i.e., Globitermes sulphureus ( $\mathrm{n}=16 ; 47 \%)$, Microcerotermes crassus $(\mathrm{n}=11 ; 32 \%)$, and $M$. distans $(\mathrm{n}=7 ; 21 \%)$. The mean density of epigeal mounds was $1.7 \pm 1.3$ mounds per $200 \mathrm{~m}^{2}$ (range: 0-4 mounds). Mound dispersion was regular/ uniform, implying intra- and inter-specific competition in this study. The regular dispersion of termite mounds in this study is similar to that reported in Kenya by Pomeroy (2005). In general, G. sulphureus builds a hard dome-shaped earthen mound above the ground. The outer wall of the epigeal mound built by $G$. sulphureus is relatively thin and hard, whereas the inner part is soft, fragile, brain-like, and packed with termite larvae. The mounds built by Microcerotermes crassus and M. distans tend to be similar externally and internally: cone-shaped, as seen from an external view, and slightly rugged or pleated, as seen from an internal view. Differences in basal circumference (BC) and mound height ( $\mathrm{MH}$ ) were seen among three termite species, except subapical circumference (SC) $\left(\mathrm{F}_{2,31}\right.$ $=10.24 ; P<0.001$ for $\mathrm{BC}, \mathrm{F}_{2,31}=2.76 ; P=0.08$ for SC, $\mathrm{F}_{2,31}$ $=12.23 ; P<0.001$ for $\mathrm{MH}$ ) (Figure 2). Ranked by the sizes of their epigeal mounds, the species were G. sulphureus, $M$. crassus, and M. distans, respectively (Figure 2). The size of the termite mound of the genus Globitermes is generally larger than that of the genus Microcerotermes (Sawasdee, 2003). The shape and size of mound are probably determined by heat load and soil porosity rather than by other soil characters (Pomeroy, 1977).

This preliminary study revealed G. sulphureus was the most abundant species, followed by $M$. crassus and $M$. distans, respectively. These species are known to be nonfungus-growing wood feeders assigned by functional groups (Davies, 1997). Globitermes sulphureus and M. crassus are common species in open and dry forests (Chaikuad et al., unpublished data), and M. distans is a common species in dry evergreen and moist evergreen forests in Kanchanaburi Province, Thailand (Vongkaluang et al., unpublished data). Watanabe et al. (1984) found that relatively dry areas, such as disturbed forests that used to be primary forests, were suitable for termite species, particularly those from genera Microcerotermes and Globitermes. Thipsantia (2011) substantiated that M. crassus and G. sulphureus are termites that can adapt to dry areas such as dry dipterocarp forests, where short food supply and habitat destruction may occur infrequently. In addition, the abundance of termites found in such forests showed a positive correlation with soil moisture, but a negative correlation with soil temperature (Thipsantia, 2011).

To our knowledge, this study is one of only a few analyses that have tried to investigate the association between termites and the physicochemical properties of their mound soils in the mixed deciduous forests of Thailand. Termites are soil and dead wood dwellers and their occurrence and functional group composition varies with the intensity of habitat disturbance (Luke et al., 2014). All termite feeding groups (i.e., dead wood and grass feeders, dead wood and leaf litter feeders, soil feeders etc.) rarely inhabit relatively disturbed sites (Luke et al., 2014). At our study site as well as in nearby areas, manmade fires were a regular occurrence, happening almost every year in the dry season (pers. obs.). Possibly, frequent fire is a reason to keep termite abundance and diversity low in our study area. The reduced complexity of the ground cover layer and the larger areas of exposed ground following 
fires possibly affect the success of mate-finding and colony establishment by termites (Davies, 1997). Another study by Abensperg-Traun \& Milewski (1995) showed that termite abundance and diversity in a fire-protected area in Australia were lower after a severe fire because of the destruction of termite colonies and a reduction in leaf litter availability.
(A)

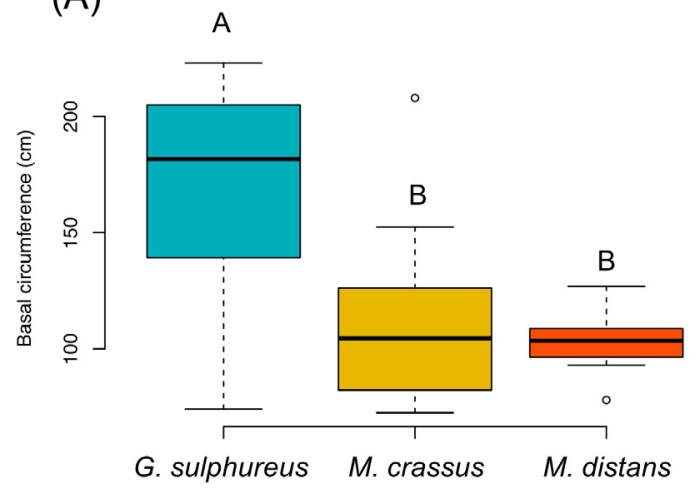

(C)

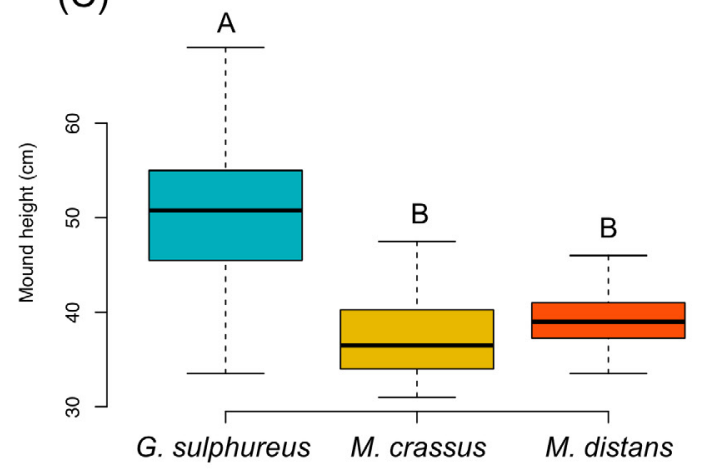

(B)

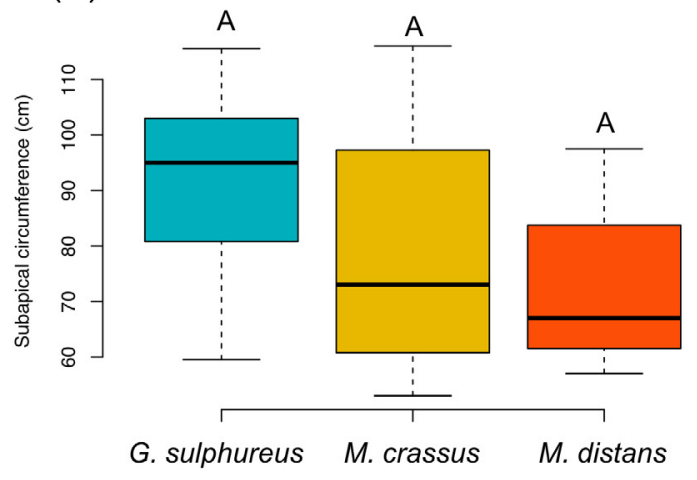

Figure 2. The difference in three dimensions of termite mounds: (A) basal circumference $(\mathrm{cm})$, (B) subapical circumference (cm), and (C) mound height $(\mathrm{cm})$. The mound dimensions are displayed by boxplot. The same capital letters above boxplots in each species denote no statistical difference (one-way ANOVA followed by Tukey's HSD test, $\alpha=0.05$ ).

\subsection{The physicochemical properties of mound soils and termite species}

We did not observe any significant differences in seven physicochemical attributes of mound soils among three termite species, except for soil $\mathrm{pH}(P<0.1)$ and silt percent $(P=0.034)$ (Table 1). The PCA based on seven mound soil attributes revealed three PCs with eigenvalues $>1.0$, accounting for $74.64 \%$ of the total variance in the physicochemical conditions (Table 2). Pearson's correlations revealed that termite mounds with $\mathrm{PC} 1$ had high soil moisture, high soil $\mathrm{pH}$, and high percent of sand and silt but low percent clay, whereas termite mounds with PC2 had high soil moisture and soil $\mathrm{pH}$ but low electrical conductivity. Termite mounds with the PC3 had high soil moisture, high electrical conductivity, and high soil temperature but low percent of silt (Table 2). A plot of individual component scores along the PC1 ( $\mathrm{x}$-axis) and PC2 (y-axis) (Figure 3) showed no separation of mound individuals among the three termite species. No clear pattern in the physicochemical characteristics of mounds separated the three termite species. This finding suggests that the soil and weather conditions at the study site provided a suitable habitat for all three species of wood feeders. 
Table 1. A comparison of the physicochemical factors (means \pm 1 SE) of mound soils among three termite species: G. sulphureus, $M$ crassus, and $M$. distans.

\begin{tabular}{lccc}
\multicolumn{1}{c}{$\begin{array}{c}\text { Physicochemical factors } \\
\text { of mounds }\end{array}$} & $\begin{array}{c}\text { G. sulphureus } \\
(n=16)\end{array}$ & $\begin{array}{c}\text { M. crassus } \\
(n=11)\end{array}$ & $\begin{array}{c}\text { M. distans } \\
(n=7)\end{array}$ \\
\cline { 2 - 4 } & $12.28 \pm 0.44 \mathrm{a}$ & $12.80 \pm 0.72 \mathrm{a}$ & $11.89 \pm 0.50 \mathrm{a}$ \\
\hline Soil moisture $(\%)$ & $126.78 \pm 4.05 \mathrm{a}$ & $123.27 \pm 3.68 \mathrm{a}$ & $116.79 \pm 3.18 \mathrm{a}$ \\
\hline EC $(\mu \mathrm{s} / \mathrm{cm})$ & $30.85 \pm 0.61 \mathrm{a}$ & $29.95 \pm 0.59 \mathrm{a}$ & $30.68 \pm 0.36 \mathrm{a}$ \\
\hline Soil temperature $\left({ }^{\circ} \mathrm{C}\right)$ & $6.99 \pm 0.04 \mathrm{a}$ & $6.88 \pm 0.05 \mathrm{a}$ & $7.11 \pm 0.08 \mathrm{~b}$ \\
\hline Soil pH & & & $48.15 \pm 3.31 \mathrm{a}$ \\
\hline Particle size distribution & $41.27 \pm 3.70 \mathrm{a}$ & $35.43 \pm 4.89 \mathrm{a}$ & $49.56 \pm 3.25 \mathrm{a}$ \\
\hline \% clay $(<0.002 \mathrm{~mm})$ & $57.20 \pm 3.66 \mathrm{a}$ & $62.15 \pm 4.74 \mathrm{a}$ & $2.29 \pm 0.25 \mathrm{a}$ \\
\hline \% sand $(2.0-0.05 \mathrm{~mm})$ & $1.53 \pm 0.11 \mathrm{a}$ & $2.42 \pm 0.31 \mathrm{~b}$ & \\
\hline \% silt $(0.05-0.002 \mathrm{~mm})$ & & & \\
\hline
\end{tabular}

Different letters following the values of means \pm 1 SE within the same row denote significant differences $(P<0.05$, one-way ANOVA, Tukey's HSD test).

Table 2. Principal component analysis (PCA) of seven soil variables for termite mounds, with Pearson's correlations between soil variables and derived principal components (PC1-PC3).

\begin{tabular}{|c|c|c|c|}
\hline \multirow{2}{*}{ Variables } & \multicolumn{3}{|c|}{ Principal components } \\
\hline & PCl & PC2 & PC3 \\
\hline Soil moisture (\%) & $0.558^{\star * *}$ & -0.282 & $0.369^{*}$ \\
\hline $\mathrm{EC}(\mu \mathrm{s} / \mathrm{cm})$ & 0.191 & $-0.726^{* * *}$ & $0.407^{*}$ \\
\hline Soil temperature $\left({ }^{\circ} \mathrm{C}\right)$ & -0.186 & $0.700^{* * *}$ & $0.423^{*}$ \\
\hline Soil pH & $0.440^{* *}$ & $0.619^{* * *}$ & 0.047 \\
\hline \multicolumn{4}{|l|}{ Particle size distribution } \\
\hline$\%$ clay & $-0.965^{* * *}$ & -0.096 & -0.045 \\
\hline$\%$ sand & $0.957^{* * *}$ & 0.103 & 0.092 \\
\hline$\%$ silt & $0.467^{\star *}$ & -0.079 & $-0.764^{\star * *}$ \\
\hline \% Variance explained in PCA & 37.73 & 21.52 & 15.39 \\
\hline Cumulative & 37.73 & 59.25 & 74.64 \\
\hline
\end{tabular}

${ }^{*} \mathrm{P}<0.05,{ }^{* *} \mathrm{P}<0.01,{ }^{* * *} \mathrm{P}<0.001$

Overall, the mean values of soil $\mathrm{pH}$ from mounds of termite species were approximately neutral $(\mathrm{pH}$ range of $6.6-7.5$, mean $\pm \mathrm{SD}=7.0 \pm 0.2, n=34$ ). However, the $\mathrm{pH}$ values were slightly but significantly higher in mound soils of $M$. distans compared to those of G. sulphureus and $D$. crassus (Table 1). The effects of termite builders on the properties of mound soils varied depending on termite functional groups. Mujinya et al. (2010) observed lower soil $\mathrm{pH}$ in termite mounds belonging to a fungus-growing termite such as Macrotermes falciger than that of the surrounding soils in the dry evergreen forests of Congo. On the contrary, Donovan et al. (2001) observed higher local soil quality and soil $\mathrm{pH}$ than that of the surrounding soils when soil passed through the guts of soil-feeding termite such as Cubitermes fungifaber in the tropical forest systems of southern Cameroon. Nutting et al. (1987) investigated the roles of generalist feeders of termites including Heterotermes aureus and Gnathamitermes perplexus in soil turnover, litter decomposition, and nutrient cycling in the Sonoran Desert grassland. From their findings, H. aureus and G. perplexus were shown to increase the soil $\mathrm{pH}$ from slightly acidic to basic by transporting belowground lime into the surface soils. In our study, it is hard to comprehend the role of wood-feeding termites like G. sulphureus, M. crassus, and $M$. distans in the $\mathrm{pH}$ values of mound soils because of a lack of comparable data concerning adjacent soils. In a recent review of 117 scientific articles by Li et al. (2017), the $\mathrm{pH}$ values of termite mounds were mainly increased by the activities of termite builders.

Termites have an influence on the modification of soil texture (Dowuona et al., 2012). In this study, we did not measure significant differences in the percentage of clay and sand particles among the three species, except the percentage of silt particles, wherein $M$. distans showed a significantly higher percentage of silt particles in termite mounds than $G$. sulphureus and M. crassus (Table 1). The percentage of sand particles was the highest, followed by a lower percentage of clay particles and the least percentage of silt particles in termite mound soils of three species (Figure 4). With an exception for the mounds of $M$. distans, they showed a high percentage of 
sand and clay particles in an equal amount and showed the least percentage of silt particles (Figure 4). We examined the association of termite species and the soil types reflected in soil particle size distribution by using the Chi-square test. The mound soil type is mostly sandy-clay in G. sulphureus (8 of
16 mounds $=50 \%$ ) and $M$. distans ( 5 of 7 mounds $=71 \%$ ), and mostly sandy-clay-loam in $M$. crassus (8 of 11 mounds $=73 \%$ ), respectively (Chi-square $=15.0 ; \mathrm{df}=6, P<0.05)$. The increasing proportion of clay particles in each soil type is presented in Figure 5.

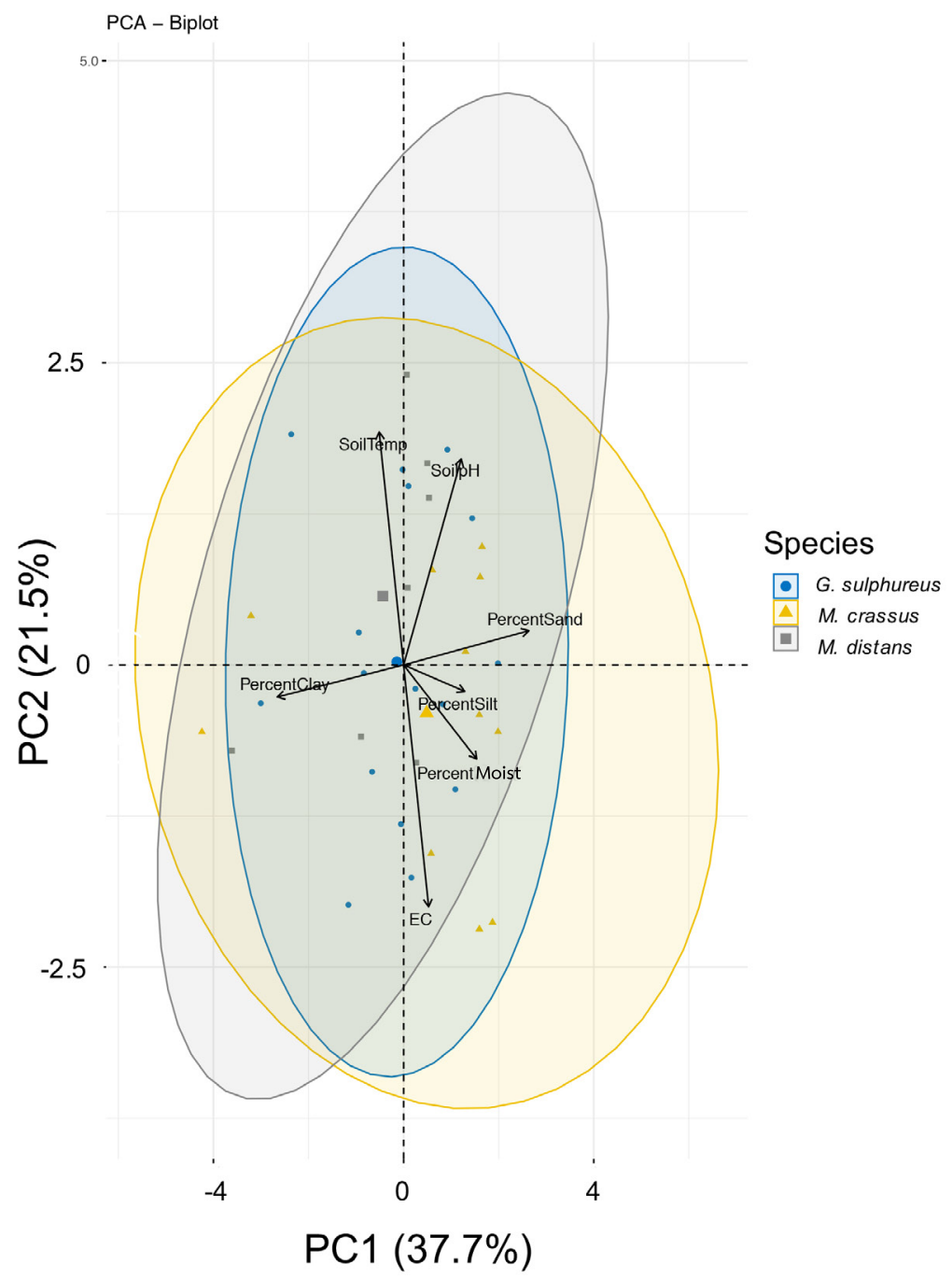

Figure 3. The principal component analysis of seven mound soil attributes from 34 specimens representing epigeal mounds of $G$. sulphureus, $M$. crassus, and M. distans. The first two axes (PC1 and PC2), together representing 59.2\% of variation. The colors and shapes of data points correspond to the termite species of mound specimens. The circled surfaces represent a $95 \%$ confidence level in the sample means with the centers of each cluster marked by larger symbols. Factor loadings are presented in Table 2. 


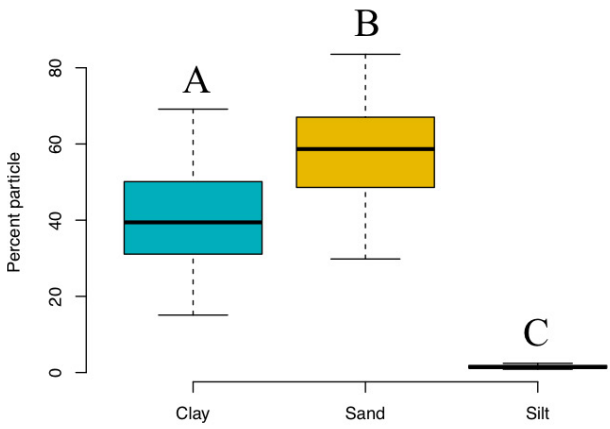

G. sulphureus

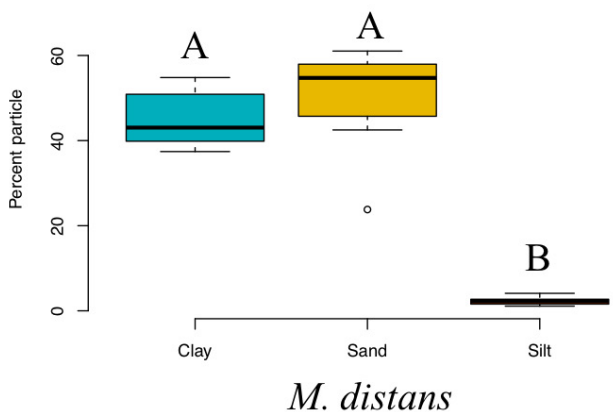

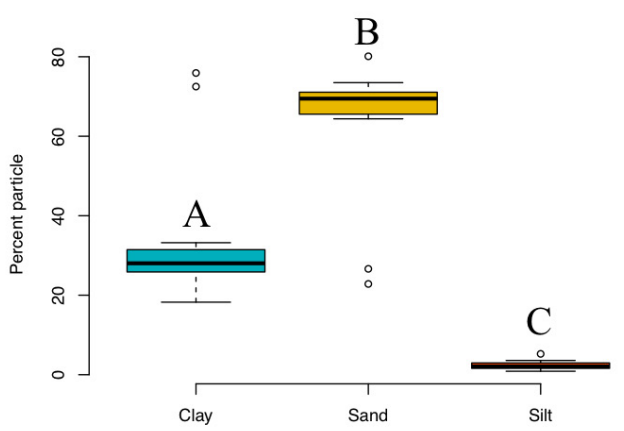

M. crassus

Figure 4. The differences in the percentage of soil particles in mounds of G. sulphureus, M. crassus, and M. distans. The percent soil particles are displayed by boxplot. The same capital letters above boxplots in each species denote no statistical difference (one-way ANOVA followed by Tukey's HSD test, $\alpha=0.05$ ).

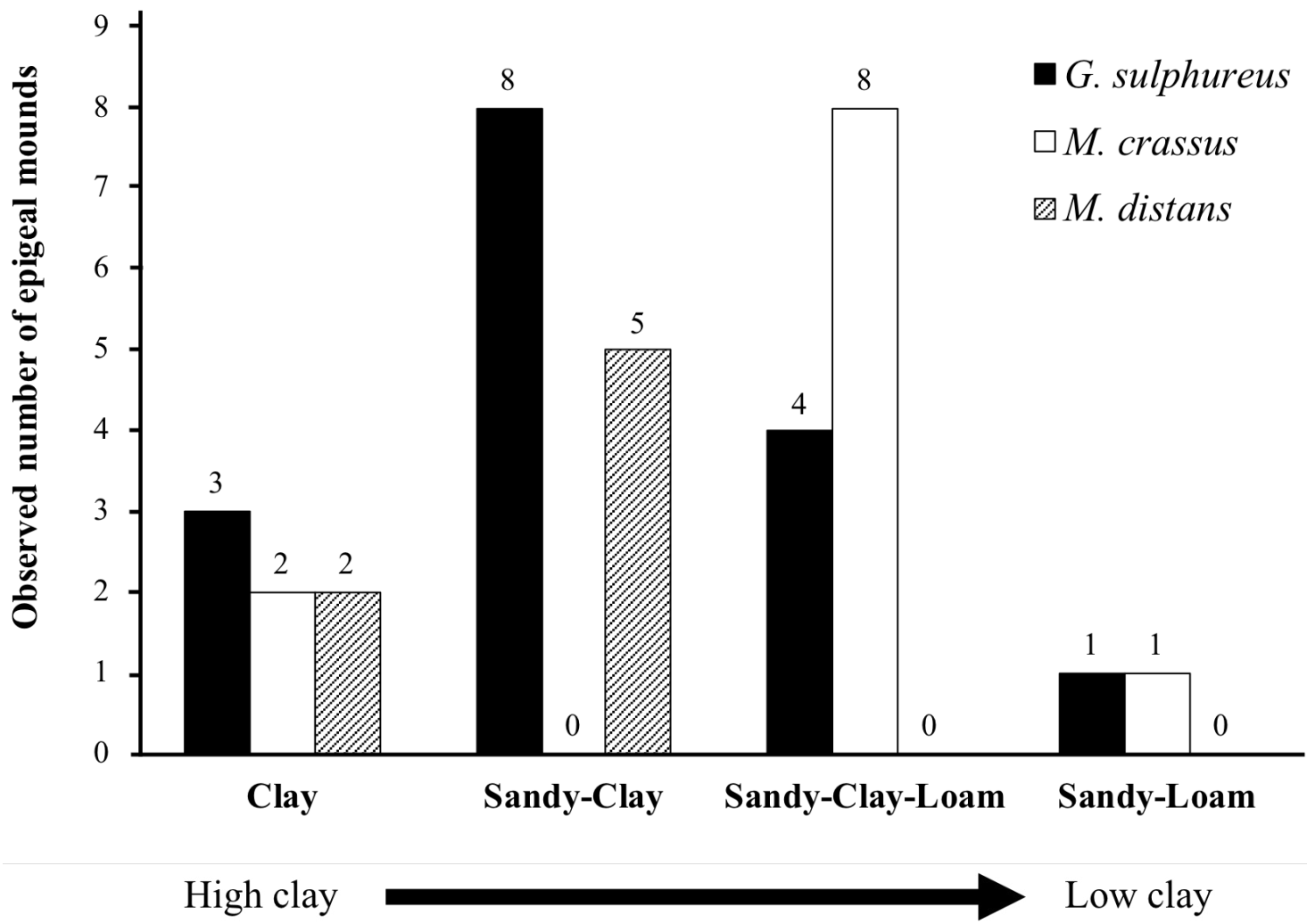

Figure 5. The frequencies of termite mounds for G. sulphureus, M. crassus, and M. distans distributed in four types of soil. 
In our study, the percentages of coarse particles (i.e., sand) and fine particles (i.e., clay) in termite mounds did not differ for three termite species, except that of intermediate particles (i.e., silt) (Table 1). Therefore, coarse sand and fine clay were the main components of the structure of termite mounds, whereas intermediate particles like silt particles comprised a small amount in mound soils for all termite species (Figure 4). This finding is in agreement with the pattern of soil texture of termite mounds in several previous studies. The analysis of particle size distribution for epigeal mounds of termites in the genera Embiratermes, Velocitermes, and Orthognathotermes from pastures of the municipality of Seropédica, Rio de Janeiro (Brazil), showed an equal proportion of clay and sand particles in a high amount, but silt particles in a low amount (Lima \& Pereira, 2018). Another study by Oliveira et al. (2012) concerning soil contents in termite mounds belonging to genus Procornitermes in the pastures of Tocantins (Brazil) observed a high proportion of clay particles in termite mounds; the clay content was also higher than that of the adjacent soils. The high proportion of clay particles in termite mounds is probably a result of the preference of termites for fine clay particles because clay contains strong cation exchange capacity (Reddy \& Perkins 1974, 1976) and is used as a cementing material for termite mounds (Donovan et al., 2001, Jouquet et al., 2004). Compared to sand particles, clay and silt particles hold much higher amounts of water (Swoboda, 2004). Clay-particle size is more important for nest building than clay mineralogy in higher termites such as Ancistrotermes cavithorax (Sjöstedt) and Odontotermes nr. pauperans (Silvestri) (Jouquet et al., 2005). The responses of termites to clay minerals of different particle sizes and mineralogy should also be determined (Wang \& Henderson, 2014; Wang et al., 2015; Lima et al., 2018).

\section{CONCLUSIONS}

We observed only three species of wood-feeding termites in this study. The mounds among three termite species had similar soil characteristics including soil humidity, electrical conductivity, and soil temperature. But soil pH and soil texture were different. Our study showed a similar proportion of clay and sand particles in termite mounds, although there was slightly higher silt content in mounds of $M$. crassus than those of other species. This study may open the door for future field research on the causal relationship between clay-sand-silt proportion and wood-feeding termites. For future study, we propose including more mound samples and other soil parameters such as clay-particle size.

\section{SUBMISSION STATUS}

Received: 12 May 2021

Accepted: 08 Jul. 2021

Associate editor: Rodrigo Studart Corrêa

\section{CORRESPONDENCE TO}

\section{Weerachon Sawangproh}

Kanchanaburi Campus, 199 M. 9, Lumsum, Sai Yok District, Kanchanaburi Province, Thailand

e-mail: weerachon.saw@mahidol.ac.th

\section{AUTHORS' CONTRIBUTIONS}

Paiphan Paejaroen

Conceptualization (Equal); Formal analysis (Equal); Investigation (Equal); Methodology (Equal); Project administration (Equal); Validation (Equal); Writing-original draft (Equal).

Chetsada Phaenark

Conceptualization (Supporting); Investigation (Supporting); Methodology (Supporting); Visualization (Supporting); Writingoriginal draft (Supporting).

Supatra Chunchob

Formal analysis (Supporting); Investigation (Supporting); Methodology (Supporting); Writing-original draft (Supporting).

Weerachon Sawangproh

Formal analysis (Equal); Investigation (Equal); Methodology (Equal); Software (Equal); Visualization (Equal); Writing-original draft (Equal); Writing-review \& editing (Equal).

\section{REFERENCES}

Abensperg-Traun M, Milewski AV. Abundance and diversity of termites (Isoptera) in unburnt versus burnt vegetation at the Barrens in Mediterranean Western Australia. Australian Journal of Ecology 1995; 20: 413-417. https://doi.org/10.1111/j.1442-9993.1995.tb00557.x

Adekayode FO, Ogunkoya MO. Comparative study of clay and organic matter content of termite mounds and the surrounding soils. African Crop Science Conference Proceedings 2009; 9: 379-384.

Apori SO, Flarian MM, Hanyabui E, Muli GK, Wamuyu B. Role of Military termites (Pseudocanthotermes militaris) in improving soil productivity in tropical agroecosystems. Annual Research \& Review in Biology 2000; 35(5): 14-19.

ASTM C136 / C136M-14. Standard Test Method for Sieve Analysis of Fine and Coarse Aggregates, ASTM International, West Conshohocken, PA; 2014; Available from: www.astm.org.

Bera D, Bera S, Chatterjee ND. Termite mound soil properties in West Bengal, India. Geoderma Regional 2020; 22: eoo293. https:// doi.org/10.1016/j.geodrs.2020.e00293

Chaikuad K, Yuharn J, Petsri A, Vilas S. Species diversity of termites in $\mathrm{Mu}$ Ko Similan National Park, Pang-nga Province. Unit of Insects and Forestry Microbiology, Division of Research and Forestry 
Development; unpublished data; Available from: http://forprod. forest.go.th/forprod/Tips/DETAILS/1005T.PDF.

Collins NM. The role of termites in the decomposition of wood and leaf litter in the southern Guinea savanna of Nigeria. Oecologia 1981; 51: 389-399. https://doi.org/10.1007/BF00540911

Davies RG. Termite species richness in fire-prone and fire-protected dry deciduous dipterocarp forest in Doi Suthep-Pui National Park, northern Thailand. Journal of Tropical Ecology 1997; 13(1): 153-160. https://doi.org/10.1017/S0266467400010348

Donovan SE, Eggleton P, Dubbin WE, Batchelder M, Dibog L. The effect of a soil-feeding termite, Cubitermes fungifaber (Isoptera: Termitidae) on soil properties: termites may be an important source of soil microhabitat heterogeneity in tropical forests. Pedobiologia 2001; 45(1): 1-11. https://doi.org/10.1078/0031-4056-00063

Dowuona GNN, Atwere P, Dubbin W, Nude PM, Mutala BE, Nartey RJ et al. Characteristics of termite mounds and associated Acrisols in the coastal savanna zone of Ghana and impact on hydraulic conductivity. Natural Science 2012; 4: 423-437. https:// doi.org/10.4236/ns.2012.47058

Eggleton P, Homathevi R, Jeeva D, Jones DT, Davies RG, Maryati $\mathrm{M}$. The species richness and composition of termites (Isoptera) in primary and regenerating lowland dipterocarp forest in Sabah, East Malaysia. Ecotropica 1997; 3: 119-128.

Jouquet P, Barre P, Lepage M. Velde B. Impact of subterranean fungus-growing termites (Isoptera, Macroter-mitinae) on chosen soil properties in a West African savanna. Biology and Fertility of Soils 2005; 41: 365-370. https://doi.org/10.1007/s00374-005-0839-6

Jouquet P, Dauber J, Lagerlöf J, Lavelle P, Lepage M. Soil invertebrates as ecosystem engineers: intended and accidental effects on soil and feedback loops. Applied Soil Ecosystem 2006; 32(2): 153-164. https:// doi.org/10.1016/j.apsoil.2005.07.004

Jouquet P, Tessier D, Lepage M. The Soil structural stability of termite nests: role of clays in Macrotermes bellicosus (Isoptera, Macrotermitinae) mound soils. European Journal of Soil Biology 2004; 40(1): 23-29. https://doi.org/10.1016/j.ejsobi.2004.01.006

Jouquet P, Traoré S, Choosai C, Hartmann C, Bignell D. Influence of termites on ecosystem functioning. Ecosystem services provided by termites. European Journal of Soil Biology 2011; 47(4): 215-222. https://doi.org/10.1016/j.ejsobi.2011.05.005

Holt JA, Lepage M. Termites and soil properties. In: Termites: Evolution, Sociality, Symbiosis, Ecology; 2000; Dordrecht: Kluwer Academic Publications; 2000. p. 389-407.

Kaiser D, Lepage M, Konaté S, Linsenmair KE. Ecosystem services of termites (Blattoidea: Termitoidae) in the traditional soil restoration and cropping system Zaï in northern Burkina Faso (West Africa). Agriculture, Ecosystems \& Environment 2017; 236: 198-211. https:// doi.org/10.1016/j.agee.2016.11.023

Kirton LG. The importance of accurate termite taxonomy in the broader perspective of termite management. In: Proceedings of the Fifth International Conference on Urban Pests; 2005; Penang, Malaysia: P\&Y Design Network; 2005. p. 1-7.

Kritasampan K, Milne JR, Srikosamatara S, Jitklang S, Jeratthitikul E. Flower-visiting arthropods of the invasive weed, Lantana camara
L. Tropical Natural History 2016; 16(1): 7-19. https://li01.tci-thaijo. org/index.php/tnh/article/view/103070

Li Y, Dong ZY, Pan DZ, Pan CH, Chen LH. Effect of termite on soil $\mathrm{pH}$ and its application for termite control in Zhejiang province, China. Sociobiology 2017; 64(3):317-326. https://doi.org/10.13102/ sociobiology.v64i3.1674

Lima SS de, Pereira, MG, Santos, GL dos, Pontes, RDM, Diniz, AR. Soil Physical and Chemical Properties in Epigeal Termite Mounds in Pastures. Floresta e Ambiente 2018; 25(1): e20160110. https:// doi.org/10.1590/2179-8087.011016

Lobry de Bruyn LA, Conacher AJ. The role of termites and ants in soil modification: a review. Australian Journal of Soil Research 1990; 28(1): 55- 93. https://doi.org/ 10.1071/SR9900055

Luke SH, Fayle TM, Eggleton P, Turner EC, Davies, RG. Functional structure of ant and termite assemblages in old growth forest, logged forest and oil palm plantation in Malaysian Borneo. Biodiversity and Conservation 2014; 23: 2817-2832. https://doi.org/10.1007/ s10531-014-0750-2

Majid AHA, Ahmad AH. Termites infestation selected from premises in Penang, Seberang Prai \& Sungai Petani, Malaysia. Malaysian Applied Biology Journal 2009; 38(2): 37-48.

Millogo Y, Hajjaji M, Morel JC. Physical properties, microstructure and mineralogy of termite mound material considered as construction materials. Applied Clay Science 2011; 52: 160-164. https://doi.org/10.1016/j.clay.2011.02.016

Mujinya BB, Adam M, Mees F, Bogaert J, Vranken I, Erens H et al. Spatial patterns and morphology of termite (Macrotermes falciger) mounds in the Upper Katanga, D.R. Congo. Catena 2014; 114: 97 106. https://doi.org/10.1016/j.catena.2013.10.015.

Mujinya BB, Ranst EV, Verdoodt A, Baert G, Ngongo LM. Termite bioturbation effects on electro-chemical properties of Ferralsols in the Upper Katanga (D.R. Congo). Geoderma 2010; 158: 233-241. https://doi.org/10.1016/j.geoderma.2010.04.033

Nutting WL, Haverty MI, LaFage JP. Physical and chemical alteration of soil by two subterranean termite species in Sonoran Desert grassland. Journal of Arid Environments 1987; 12(3): 233-239. https://doi.org/10.1016/S0140-1963(18)31167-4

Oliveira LBT, Santos AC, Silva SP No, Silva JEC, Paiva JA. Alterações físicas e químicas do solo em virtude de construções termíticas no norte de Tocantins. Engenharia Agrícola 2012; 20: 118-130. https:// doi.org/10.13083/reveng.v20i2.179

Palin O, Eggleton P, Malhi Y, Girardin CAJ, Rozas-Dávila A, Parr CL. Termite diversity along an Amazon-Andes Elevation Gradient, Peru. Biotropica 2011; 43(1): 100-107. https://doi.org/10.1111/j.17447429.2010.00650.x

Phenrat T, Otwong A, Chantharit A, Lowry GV. Ten-year monitored natural recovery of lead-contaminated mine tailing in Klity Creek, Kanchanaburi Province, Thailand. Environmental Health Perspectives 2016; 124(10): 1511-1520. https://doi.org/10.1289/EHP215

Pomeroy DE. Abundance of large termite mounds in Uganda. Journal of Applied Ecology 1977; 14(2): 465-475. https://doi. org/10.2307/2402559 
Pomeroy D. Dispersion and activity patterns of three populations of large termite mounds in Kenya. Journal of East African Natural History 2005; 94(2): 319-341. https://doi.org/10.2982/00128317(2005)94[319:DAAPOT]2.0.CO;2

R Development Core Team. R: A Language and Environment for Statistical Computing. R Foundation for Statistical Computing; 2018; Available from: https://cran-archive.r-project.org.

Reddy MR, Perkins HF. Fixation of zinc by clay minerals. Soil Science Society of America Journal 1974; 38: 229-231. https://doi. org/10.2136/sssaj1974.03615995003800020011x

Reddy MR, Perkins HF. Fixation of manganese by clay minerals. Soil Science 1976; 121: 21-24. https://doi.org/10.1097/00010694197601000-00004

Sornnuwat Y, Vongkaluang C, Takematsu Y. A systematic key to termites of Thailand. Kasetsart Journal (Natural Science) 2004; 38: 349-368.

Rückamp D, Martius C, Bornemann L, Kurzatkowski D, Naval LP, Amelung W. Soil genesis and heterogeneity of phosphorus forms and carbon below mounds inhabited by primary and secondary termites. Geoderma 2012; 170: 239-250.

Sawasdee P. A study on the effect of edaphic factors on species and distribution of termite fauna in the tropical forest ecosystem; Master's thesis, Kasetsart University, Thailand; 2003.

Sharma D, Babel MS. Trends in extreme rainfall and temperature indices in the western Thailand. International Journal of Climatology 2014; 34: 2393-2407. https://doi.org/10.1002/joc.3846

Silva LCR, Vale GD, Haidar RF, Sternberg LSL. Deciphering earth mound origins in central Brazil. Plant and Soil 2010; 336: 3-14. https://doi.org/10.1007/s11104-010-0329-y

Swoboda LE. Environmental influences on subterranean termite foraging behavior and bait acceptance. $\mathrm{PhD}$ dissertation, Department of Entomology, Virginia Polytechnic Institute and State University, Virginia, USA; 2004.
Thongkhong V. Species identification, nest characteristic and bait control of termite in Para rubber plantation, southern Thailand; Master's thesis, Prince of Songkla University, Thailand; 2009.

Thipsantia P. Biodiversity of termites and their relationship to dry dipterocarp and dry evergreen ecosystems at Sakaerat environmental research station, Nakhon Ratchasima Province; Master's thesis, Suranaree University of Technology, Thailand; 2011.

Tienwong K, Dasananda S, Navanugraha C. Integration of land evaluation and the analytical hierarchical process method for energy crops in Kanchanaburi, Thailand. ScienceAsia 2009; 35: 170177. https://doi.org/10.2306/scienceasia1513-1874.2009.35.170

Vongkaluang C, Sornnuwat Y, Charoenkrung K, Chutibhapakorn S, Yoko T. Survey and study on ecology and diversity of termites in eastern and western Thailand; Chantaburi and Kanchanaburi Province; unpublished data; p. 1-7. Available from: http://forprod. forest.go.th/forprod/Tips/DETAILS/1004T.PDF.

Wang C, Henderson G. Clay preference and particle transport behavior of Formosan subterranean termites (Isoptera: Phinotermitidae): A laboratory study. Insect Science 2014; 21 : 785-795. https://doi.org/10.111/1744-7917.12082

Wang C, Henderson G, Gautam BK. 2015. Behavioral response of Formosan subterranean termites (Isoptera: Rhinotermitidae) to soil with high clay content. Journal of Insect Behavior 2015; 28 : 303-311. https://doi.org/10.1007/s10905-015-9505-5

Watanabe H, Takeda H, Ruaysoongnern S. Termites of Northeastern Thailand with Special Reference to Changes in Species Composition due to Shifting Cultivation. Memoirs of the College of AgricultureKyoto University (Japan) 1984; 125: 45-57.

Whitford W, Eldridge D. Effects of ants and termites on soil and geomorphological processes. Treatise on Geomorphology 2013; 12: 281-292. https://doi.org/10.1016/B978-0-12-374739-6.00335-3 